\title{
Bell Pepper Development and Water Potential as Affected by Soil Water Tensions and Nitrogen Doses
}

Helane Cristina Aguiar Santos, Joaquim Alves de Lima Junior, William Lee Carrera de Aviz, Deiviane de Souza Barral, Renan de Souza

Universidade Federal Rural da Amazônia, Brazil

Lívia Tálita da Silva Carvalho, Thiago Feliph Silva Fernandes

Universidade Estadual Paulista “Júlio de Mesquita Filho”, Brazil

Eduardo Cezar Medeiros Saldanha

Yara Fertilizantes, Brazil

Mário Lopes da Silva Junior, Paulo Jorge de Oliveira Ponte de Souza

Universidade Federal Rural da Amazônia, Brazil

Received: Mar. 12, 2020

Accepted: Apr. 11, 2020

Published: Apr. 16, 2020

doi:10.5296/jas.v8i2.16651

URL: https://doi.org/10.5296/jas.v8i2.16651

\begin{abstract}
Considering the lack of technical information on the water depth and nitrogen fertilization via fertigation in bell pepper cultivation, this work aimed to provide management data for its production in the northern region of Brazil. The experiment was carried out in a greenhouse at FEIGA / UFRA, with a $1.0 \times 0.50 \mathrm{~m}$ spacing, in a randomized block design, with a $5 \times 4$ factorial scheme, with three replications. The treatments consisted of five water tensions in the soil $(15,25,35,45$ and $65 \mathrm{kPa})$ and four nitrogen doses $\left(0,135,265\right.$ and $\left.395 \mathrm{~kg} \cdot \mathrm{ha}^{-1}\right)$. There was no interaction between the factors of water tension in the soil and nitrogen doses for any of the variables analyzed. Height of plants, fresh shoot mass and dry shoot mass showed significant differences only for nitrogen doses. Predawn potential, showed significant difference for soil water tensions and nitrogen doses. Ahead of the conditions under which this work was carried out and the results obtained for the variables analyzed for the bell pepper cultivation in a protected environment, we found that the soil water tension of $15 \mathrm{kPa}$
\end{abstract}


and the nitrogen dose of $265 \mathrm{~kg} \cdot \mathrm{ha}^{-1}$ were ideal for the crop.

Keywords: Capsicum annuиm L., greenhouse, fertirrigation, tensiometry

\section{Introduction}

Bell pepper is one of the most economically important vegetables in Brazil and in the world. It is among the most cultivated species in protected environments in Brazil (Flores, 2014; Loss, 2017), because this type of cultivation has advantages such as efficiency in water use and greater yield and product quality. Additionally, produce are available throughout the year due to the better use of production factors, such as fertilizers and pesticides, besides the total climate control (Filgueira, 2008).

Nitrogen requires special management regarding its fertilization, because it is easily leached, because the crop absords varied amounts along the cycle and because it directly acts on plant growth (Aragão et al. 2012). In a protected environment, doses of up to $266 \mathrm{~kg} \mathrm{ha}^{-1}$ of nitrogen in the bell pepper crop were responsible for increasing the amount of nutrients in the stem, leaves and aerial part (Araújo et al., 2009), since the supply of optimal doses of nitrogen promotes the vegetative growth and expansion of the photosynthetically active area.

These authors report that nitrogen application for bell pepper in protected environment is exaggerated, since the doses must be different from those applied in the field, so that the plant receives the ideal quantity of fertilizers, avoiding wastes and soil salinization, because in this system there are no rains, which contributes to this salinization. Works such as that of Campos et al. (2008), showed that the cultivation of bell pepper greenhouse house of vegetation responded positively to the use of nitrogen in fertigation.

Fertigation is the process of applying fertilizers via irrigation water and, according to Carrijo et al. (2004), it aims to provide quantities of nutrients required by the crop in the appropriate moment in order to obtain high yields and quality products. In addition, it include from the selection of sources and forms of nutrients to the establishment of the frequency and splitting of the applications along the crop cycle (Marouelli \& Silva, 2014). Because of that, it has been widely practiced by producers.

In scientific studies, the most used method of irrigation management is the management via monitoring of soil water tension because, according to Carvalho et al. (2013), it is a low-cost product and occupies a small space in the protected environment. According to Flores (2014), tension measurements in the soil profile enable the estimation of the amount of water to be applied by irrigation, which can be obtained with the aid of a soil water retention curve (Marouelli \& Silva, 2014), which one relates water content in the soil to the tension with which this water is retained.

According to Marouelli \& Silva (2014), for the correct management and recognition of the water conditions of the crop, it is necessary to monitor it using various equipment and parameters. Scholander's pressure chamber and tensiometers, for example, are used to monitor plant and soil potentials, respectively. Based on this information, the leaf water potential can be compared with the total water potential in the soil and, thus, the ranges that indicate the need 
for irrigation are established. On the other hand, soil tensiometers monitor the availability of water from the matric potential.

Therefore, this work aims to evaluate the effect of different water tensions in the soil and nitrogen doses via fertigation on the vegetative development and water potential of bell peppers.

\section{Materials and Methods}

The study was carried out in a protected environment, covered by a 150 micron plastic film and a 50\% shade net, located at the Fazenda Escola of Igarapé-Açu, a campus that belongs to the Federal Rural University of Amazon (FEIGA / UFRA), at the geographical coordinates of $1^{\circ} 07^{\prime} 48.47^{\prime \prime S}$ and $47^{\circ} 36^{\prime} 45.31^{\prime \prime} \mathrm{W}$, northeast region of Pará State.

The experimental design was in randomized blocks in a $5 \times 4$ factorial scheme, with three replications. The treatments consisted of five water tensions in the soil $(15,25,35,45$ and 65 $\mathrm{kPa})$ as an indication of the moment of irrigation - critical tension, and four doses of nitrogen ( 0 , 135, 265 and $395 \mathrm{~kg} \cdot \mathrm{ha}^{-1}$ ) based on the nutrient absorption curve for fertigated bell pepper (Rincón et al. 1995), corresponding to 0, 45, 90 and 135\% nitrogen indicated by the authors.

The hybrid used was DAHRA RX and the seedlings were prepared in polyethylene trays, filled with organic compost. At the $30^{\text {th }}$ day after sowing (DAS), with an average of $15 \mathrm{~cm}$ in height, the seedlings were transplanted. They were irrigated for 30 days, before the differentiation of treatments, the total water depth applied over this period was $199.08 \mathrm{~mm}\left(6.64 \mathrm{~mm} \mathrm{day}{ }^{-1}\right)$. After these 30 days after transplantation (DAT), differentiation of treatments began.

Soil preparation was carried out 30 days before transplanting, with application of lime in the 0-20 cm layer, incorporated with a hoe. Then, the soil was corrected by the base saturation method (Table 1) in order to correct soil acidity and increase base saturation (V) to 80\%, which reacted for 30 days. One week before transplanting the seedlings, basal fertilization was performed by the application of Topmix ${ }^{\mathrm{Tm}}(08.40 .08+\mathrm{S}+$ micronutrients $-\mathrm{Zn}, \mathrm{B}, \mathrm{Cu}$ and $\mathrm{Mn})$, $50 \mathrm{~g} \mathrm{~m}^{-2}$, in all plots.

Table 1. Chemical analysis of the soil

\begin{tabular}{|c|c|c|c|c|c|c|c|c|c|c|c|c|c|}
\hline \multirow{3}{*}{ Depth } & \multicolumn{13}{|c|}{ Chemical analysis } \\
\hline & \multicolumn{4}{|c|}{ Macronutrients } & \multicolumn{4}{|c|}{ Micronutrients } & \multicolumn{2}{|c|}{ Acidity } & \multicolumn{3}{|c|}{ Others } \\
\hline & $\mathrm{K}$ & $\mathrm{P}$ & $\mathrm{P} \mathrm{Ca}$ & $\mathrm{Mg}$ & $\mathrm{Cu}$ & $\mathrm{Fe}$ & $\mathrm{Mn}$ & $\mathrm{Zn}$ & $\mathrm{pH}$ & $\mathrm{H}+\mathrm{Al}$ & $\mathrm{V}$ & CEC & $\mathrm{OM}$ \\
\hline $\mathrm{cm}$ & $\underset{\mathrm{dm}^{-3}}{\mathrm{mg}}$ & & cmolc & $\mathrm{dm}^{-3}$ & & mg & $\mathrm{lm}^{-3}-$ & --- & $\mathrm{H}_{2} \mathrm{O}$ & $\underset{\mathrm{dm}^{-3}}{\text { cmolc }}$ & $\%$ & $\begin{array}{c}\text { cmolc } \\
\mathrm{dm}^{-3}\end{array}$ & $\begin{array}{c}\mathrm{g} \\
\mathrm{kg}^{-1}\end{array}$ \\
\hline $0-20$ & 74 & 26 & 1.6 & 0.8 & 0.95 & 493.64 & 6.65 & 2.31 & 4.7 & 3.63 & 42.13 & 6.27 & 11.37 \\
\hline
\end{tabular}

Source: Soil Analysis Laboratory of Embrapa Eastern Amazon 


\section{Macrothink}

The localized irrigation system adopted was drip system, with an average flow rate of 2.32 L.h ${ }^{-1}$ per dripper, and emitters spaced $15 \mathrm{~cm}$ apart. Irrigation was carried out through drip hoses with nominal diameter of $16 \mathrm{~mm}$ and at operating pressure of $7.5 \mathrm{~m}$.w.c. gauged by a manometer at the end of the hose. The drip hoses were positioned inside the plot, and each hose served one row of plants (3.5 drippers / plant). A $3000 \mathrm{~L}$ water tank, a $1.5 \mathrm{hp}$ electric pump (10 $\mathrm{m}^{3} \cdot \mathrm{h}^{-1}$ flow) operated by the controller and a disc filter were used for the irrigation system.

After setting up irrigation system, a hydraulic evaluation was carried out to determine its performance, through the Distribution uniformity coefficient (DUC) (Equation 1). The uniformity analysis was carried out in 30 plots, by placing $180 \mathrm{~mL}$ collection containers under four emitters and collecting water for a period of $1 \mathrm{~min}$, with two repetitions. Through the averages of the collected volumes, the DUC was calculated. The system classified as excellent (96\%) according to the classification of Mantovani (2001).

$$
D U C=\frac{q_{25}}{q_{m}} \cdot 100
$$

In which:

DUC - Distribution uniformity coefficient (\%)

$q_{25}$ - Average of $25 \%$ of the lowest flows.

$q_{m}$ - Average of all flows in $\mathrm{L} \mathrm{h}^{-1}$.

In order to determine the critical tension, two puncture tensiometers were installed at $20 \mathrm{~cm}$ and another one at $30 \mathrm{~cm}$ depth. The first two served to indicate the moment of irrigation, while the other was used to check if water loss was occurring. The tensiometers were positioned along the crop row, $15 \mathrm{~cm}$ away from the drippers. Tensiometer readings were performed once a day, at the same time, using a digital puncture tensimeter.

Irrigation management was based on the soil-water characteristic curve obtained in the $0-30 \mathrm{~cm}$ profile. The moisture contents were fitted according to the model proposed by Van Genuchten (1980) (Figure 1). Irrigations were carried out when the mean of the tensiometers reached the critical tension, and always trying to raise soil moisture to field capacity, which corresponded to the tension of $10 \mathrm{kPa}\left(0,339 \mathrm{~cm}^{3} \mathrm{~cm}^{-3}\right)$. 


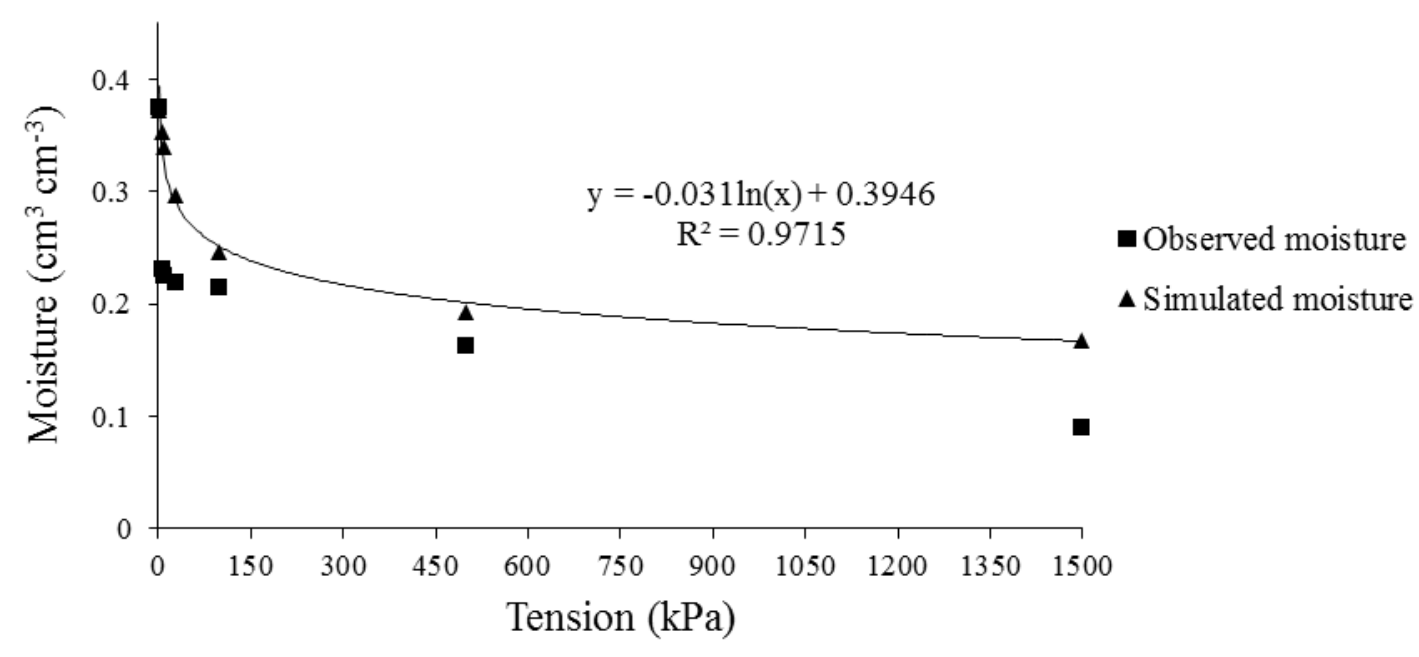

Figure 1. Soil water retention curve

The water depths applied in the differentiation of treatments and irrigation system the operating time were calculated according to Cabello (1996), considering the effective depth of the root system equal to $20 \mathrm{~cm}$, as about $80 \%$ of crop roots are concentrated at this depth (Marouelli, 2008).

The injection pump system was adopted to apply the fertilizers. The fertilizer solution, contained in the open reservoir, was injected into the irrigation system with a pressure $10 \%$ higher than that at the discharge pipe, at constant concentration, through the 1 hp electric pump $\left(9.8 \mathrm{~m}^{3} \mathrm{~h}^{-1}\right)$, operated by the controller. A manometer was installed after the disc filter to better control the system's operating pressure.

The fertilizers were applied as a mixture, the solutions were prepared separately and then mixed, in the desired proportion, according to the treatments, always taking into account the solubility and compatibility of the sources used. In addition, before the injection, the electrical conductivity of the concentrated nutrient solution $\left(\mathrm{dS} \mathrm{m}^{-1}\right)$ was checked. Therefore, the amount required by each treatment was weighed, identified and diluted in water (considering its solubility and compatibility) based on the absorption curve of fertigated bell pepper (Rincón et al., 1995) (Table 2). 


\section{Ml Macrothink}

Table 2. Nutrient absorption curve used as a reference

\begin{tabular}{|c|c|c|c|c|c|c|c|c|c|c|}
\hline \multirow{2}{*}{$\begin{array}{c}\begin{array}{c}\text { Period } \\
\text { days }\end{array} \\
0-35\end{array}$} & \multirow{2}{*}{$\begin{array}{l}\mathbf{N} \\
---- \\
0.05\end{array}$} & $\begin{array}{ll}\mathbf{P}_{2} \mathbf{O}_{5} & \mathbf{K}\end{array}$ & $\mathrm{CaO}$ & \multicolumn{2}{|c|}{ MgO } & \multirow{2}{*}{$\begin{array}{c}\mathbf{N} \mathbf{P}_{2} \mathrm{O}_{5} \\
2\end{array}$} & \multirow{2}{*}{$\begin{array}{r}\mathbf{K}_{2} \mathbf{O} \\
\mathrm{Kg} \text { ha } \\
0\end{array}$} & \multirow{2}{*}{$\begin{array}{c}\mathbf{C a O} \\
\text { period }\end{array}$} & \multicolumn{2}{|c|}{$\mathrm{MgO}$} \\
\hline & & 0.009 & 0.10 & 0.06 & $\begin{array}{c}0.02 \\
5\end{array}$ & & & & 2 & 1 \\
\hline $35-55$ & 0.35 & 0.07 & 0.80 & 0.35 & 0.17 & 7 & 1 & 16 & 7 & 3 \\
\hline $55-70$ & 1.20 & 0.23 & 2.25 & 0.98 & 0.45 & 18 & 3 & 34 & 15 & 7 \\
\hline $70-85$ & 1.30 & 0.23 & 2.60 & 0.98 & 0.41 & 20 & 3 & 39 & 15 & 6 \\
\hline $85-100$ & 2.60 & 0.78 & 4.82 & 2.80 & 1.41 & 39 & 12 & 72 & 42 & 21 \\
\hline $100-120$ & 2.75 & 0.57 & 5.50 & 1.12 & 1.16 & 55 & 11 & 110 & 22 & 23 \\
\hline $120-140$ & 3.75 & 1.08 & 4.82 & 1.40 & 1.00 & 75 & 22 & 96 & 28 & 20 \\
\hline $140-165$ & 3.15 & 0.78 & 4.80 & 1.68 & 1.19 & 79 & 19 & 120 & 42 & 30 \\
\hline Total/100t & & & & & & 294 & 73 & 491 & 173 & 111 \\
\hline Total/t & & & & & & 2.9 & 0.7 & 4.9 & 1.7 & 1.1 \\
\hline
\end{tabular}

Source: Rincón et al. (1995)

The fertilizers used in the fertigation solution were: calcium nitrate, potassium nitrate, magnesium nitrate, urea, calcium chloride, potassium chloride (white powder), purified MAP, monopotassium phosphate and magnesium sulfate. The application of fertilizers was carried out according to the replacement of the irrigation depths of the tension corresponding to each treatment.

Soil solution was monitored using extractors, at a depth of $20 \mathrm{~cm}$, following the same methodology for installing tensiometers. In order to extract the solution from the soil, vacuum was applied to all extractors after fertigation. After $24 \mathrm{~h}$ of this application, the solution was extracted with the aid of a $60 \mathrm{~mL}$ plastic syringe and analyzed with a portable multiparameter meter (AKSO ${ }^{\circledR}$ Combo5), checking hydrogen potential $(\mathrm{pH})$, electrical conductivity (EC), salinity (Sal) and total dissolved solids (TDS).

Table 3 presents the water depths applied before (Init) and after the differentiation of treatments (Irrig), which occurred during the experiment, the total water supplied to the crop until the harvest (Total), the number of irrigations (NI), average irrigation interval (Int) and daily water demand (WD) during treatment differentiation. The differentiation of treatments occurred only at the $30^{\text {th }}$ DAT. 
Table 3. Soil water tensions at $0.20 \mathrm{~m}$ depth, water depths applied before differentiation of treatments (Init), water depths applied after differentiation of treatments (Irrig), total water depth (Total), number of irrigations (NI), mean irrigation interval (Int) and daily water demand (WD) in bell pepper cultivation as a function of soil water tensions and nitrogen doses via fertigation, Igarapé-Açu - PA, Brazil, 2018

\begin{tabular}{cccccccc}
\hline \multicolumn{7}{c}{ Water depths $(\mathrm{mm})$} \\
Treatments & Tension & Init & Irrig & $\begin{array}{c}\text { Tot } \\
\text { al }\end{array}$ & $\begin{array}{c}\text { NI } \\
(\text { un })\end{array}$ & Int & $\begin{array}{c}\text { WD } \\
\text { (mm/day) }\end{array}$ \\
\hline T15 & $15 \mathrm{kPa}$ & 199.08 & 320.80 & 519.88 & 48 & 2.31 & 4.68 \\
T25 & $25 \mathrm{kPa}$ & 199.08 & 314.34 & 513.42 & 32 & 3.47 & 4.63 \\
T35 & $35 \mathrm{kPa}$ & 199.08 & 305.53 & 504.61 & 25 & 4.44 & 4.55 \\
T45 & $45 \mathrm{kPa}$ & 199.08 & 271.80 & 470.88 & 17 & 6.53 & 4.24 \\
T65 & $65 \mathrm{kPa}$ & 199.08 & 209.23 & 408.31 & 11 & 10.09 & 3.68 \\
\hline
\end{tabular}

We observed that the total water depth applied was decreasing, where the tension of $15 \mathrm{kPa}$ was associated with the highest water consumption, given the highest number of irrigations, since this tension is close to the field capacity adopted in this experiment.

According to Marouelli and Silva (2012), the water requirement of bell pepper is between 450 and $650 \mathrm{~mm}$, depending essentially on the adopted systems of cycles of time and irrigation. Likewise, Doorenbos \& Kassam (2000) stated that the total water needs of this crop range from 600 to $900 \mathrm{~mm}$, possibly reaching up to $1250 \mathrm{~mm}$ for long growth periods with several harvests. The treatments are within the interval established in the literature, except for the one with $65 \mathrm{kPa}$ tension.

The variables evaluated were: Height of plants (HP), fresh shoot mass (FSM), dry shoot mass (DSM) and predawn water potential (PWP).

Height of plants was measured using a measuring tape. We placed its end at the base of the plant close to the ground and put it vertically towards the top of the plant. The last leaf insertion of the highest branch was considered as the reading point, in centimeters (Bilibio et al. 2010).

The plants were cut close to the ground, placed in paper bags and weighed to obtain the fresh mass. After that, they were dried in a forced air circulation oven, at $65^{\circ} \mathrm{C}$, until a constant mass was obtained. Then, they were weighed, on a semi-analytical scale, with two decimal places. Five plants were sampled per treatment.

In order to monitor water availability in the soil, measurements of predawn leaf water potential (PWP) were performed using the Scholander's pressure chamber (Scholander et al. 1965), 


\section{Al Macrothink}

Journal of Agricultural Studies

ISSN 2166-0379

2020, Vol. 8, No. 2

model M 1505D (Pressure Chamber Instruments, PMS), on healthy fully expanded leaves, collected in the middle third of the plants.

For the statistical analysis of the data, we performed the analysis of variance, according to the effects of soil water tension and nitrogen fertilization via fertigation. Subsequently, the data were subjected to regression analysis, with curve fitting at the 5\% level of significance, according to the parameters evaluated. The software R 3.5.0 was used for data analysis.

\section{Results and Discussion}

Regarding the data obtained in this work, we observed that there was no interaction between the factors of water tensions in the soil and nitrogen doses for the analyzed variables, at the 5\% level of significance. Height of plants, fresh shoot mass and dry shoot mass showed significant differences only for the doses of nitrogen. On the other hand, the predawn water potential showed a significant difference for the water tensions in the soil and nitrogen doses, in which the water tension levels in the soil and nitrogen doses had a significant effect at $5 \%$ probability level (Table 4).

Table 4. Summary of the variance analysis for height of plants (HP), fresh shoot mass (FSM), dry shoot mass (DSM) and predawn water potential (PWP) as a function of soil water tensions and nitrogen doses via fertigation in the bell pepper crop, Igarapé Açu-PA, 2018

\begin{tabular}{ccccc}
\hline & \multicolumn{4}{c}{ F values } \\
$\begin{array}{c}\text { Source of } \\
\text { Variation }\end{array}$ & HP & FSM & DSM & $\Psi_{\text {Am }}$ \\
\cline { 2 - 5 } & -- cm -- & -------- g -------- & MPa \\
\hline Block & $0.76^{\mathrm{ns}}$ & $3.93^{\mathrm{ns}}$ & $0.39^{\mathrm{ns}}$ & $6.87^{\mathrm{ns}}$ \\
Tension (T) & $3.87^{\mathrm{ns}}$ & $0.00^{\mathrm{ns}}$ & $0.11^{\mathrm{ns}}$ & $10.81^{*}$ \\
Nitrogen (N) & $5.15^{*}$ & $16.64^{*}$ & $16.61^{*}$ & $22.44^{*}$ \\
Interaction T x N & $0.69^{\mathrm{ns}}$ & $0.00^{\mathrm{ns}}$ & $0.30^{\mathrm{ns}}$ & $0.04^{\mathrm{ns}}$ \\
\hline CV $(\%)$ & 10.58 & 29.35 & 29.93 & 26.44 \\
\hline
\end{tabular}


The data of height of plants followed a quadratic trend curve $(P<0.05)$. The optimal dose estimated by the fitting equation $\left(\mathrm{R}^{2}>0.9\right)$ was $224.33 \mathrm{~kg} \cdot \mathrm{ha}^{-1}$ for a maximum height of 77.66 $\mathrm{cm}$ (Figure 3).

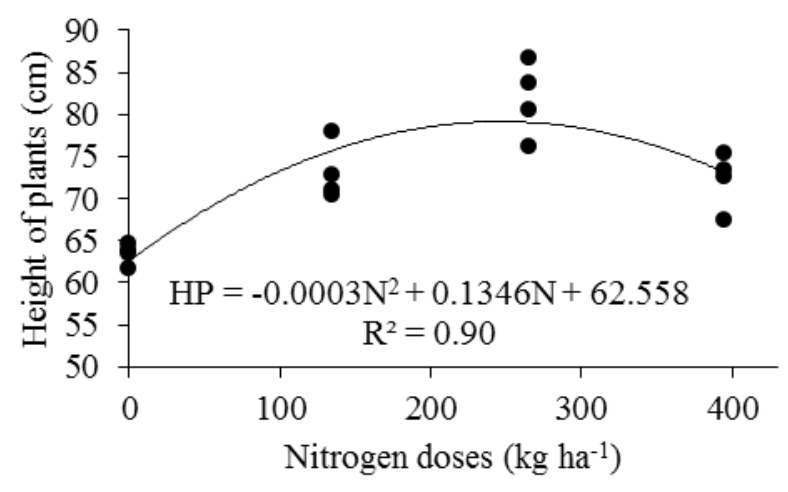

Figure 3. Effect of nitrogen doses via fertigation on height of plants (HP), in the bell pepper crop

Bell pepper plants that received nitrogen grew with greater vigor when compared to plants that did not receive the nutrient, because the absence of nitrogen limits plant growth and its low availability is associated with reductions in cell division and expansion, leaf area and photosynthesis (Carvalho, 2005), besides stimulating the formation of flower and fruit buds (Malavolta et al., 1997).

Working with doses ranging from 0 to $400 \mathrm{~kg} \mathrm{ha}^{-1}$ applied via fertigation in a protected environment, Araújo (2005) found increasing linear response up to the dose of $400 \mathrm{~kg} \mathrm{ha}^{-1}$, and the height of bell pepper plants was higher in treatments that received nitrogen fertilization. This is contrary to the result found in this study, in which the bell pepper plants did not respond from the dose that caused maximum height, leading to waste of fertilizer and demonstrating the importance of a correct fertilization for the yield of the crop.

In this study, the best mean of height of plants was $77.66 \mathrm{~cm}$, obtained at the ideal dose of $224.33 \mathrm{~kg} \mathrm{ha}^{-1}$, contrasting the values found by Carvalho et al. (2013), who found the best height $(50.34 \mathrm{~cm})$ in the bell pepper crop at the $\mathrm{N}$ dose of $0 \mathrm{mg} \mathrm{dm}^{-3}$, and by Araújo (2005), who found the best height $(50 \mathrm{~cm})$ of bell pepper plants at the dose of $400 \mathrm{~kg} \mathrm{ha}^{-1}$. Therefore, it can be verified that the influence of $\mathrm{N}$ on bell pepper depends on the climate, soil, hybrid and crop management.

On average, throughout the cycle, bell pepper plants grown in a greenhouse were taller than plants grown in the field (Santos et al., 1999; Filgueira, 2003; Santos et al., 2003), because they are influenced by the microclimate established in a protected environment, especially high values of temperature, reaching height between $0.40 \mathrm{~m}$ to $1.50 \mathrm{~m}$ (Flores, 2014). The average height found in the present study is consistent with the growth standard of the crop.

The fresh shoot mass followed a quadratic curve $(P<0.05)$. The optimal doses estimated by the fitting equations $\left(\mathrm{R}^{2}>0.8\right)$ were 256.09 and $233.33 \mathrm{~kg} \mathrm{ha}^{-1}$ for a maximum fresh and dry mass of $1,151.49$ and $177.15 \mathrm{~g}$, respectively (Figure 4 and 5). 


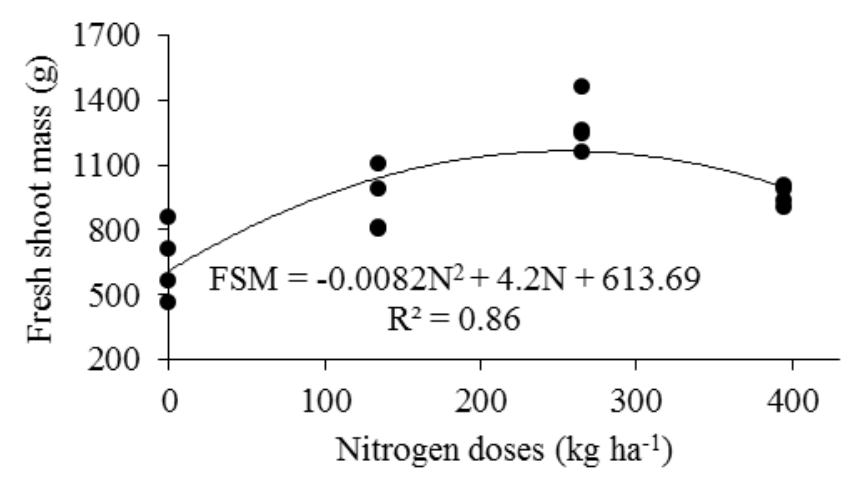

Figure 4. Effect of nitrogen doses via fertigation on fresh shoot mass (FSM), in bell pepper crop

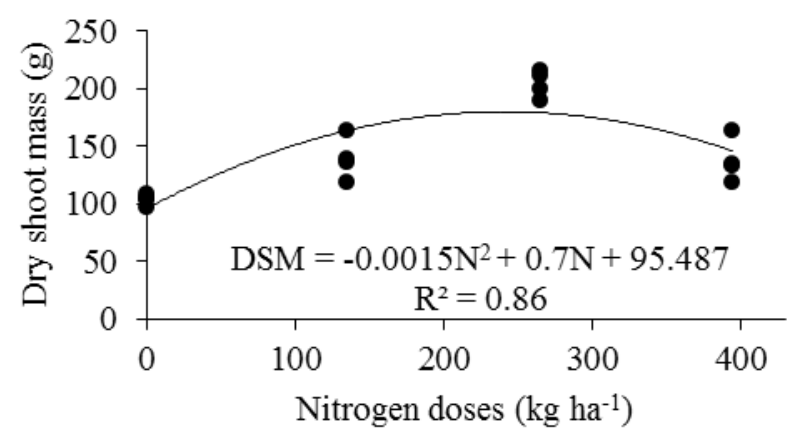

Figure 5. Effect of nitrogen doses via fertigation on dry shoot mass (DSM), in bell pepper crop

We observed that at the zero dose of nitrogen, the production of fresh shoot mass was $613.69 \mathrm{~g}$. On the other hand, the ideal dose of nitrogen led to a production of $1,151.49 \mathrm{~g}$. It is substantial increase of approximately $87.63 \%$ of fresh shoot mass in the bell pepper crop.

The production of fresh shoot mass in the bell pepper crop obtained a result similar to that found by Aviz et al. (2019), who worked with jambu in a protected environment and in the field and also observed a quadratic effect, as the use of nitrogen directly influenced the increase in fresh mass, which decreased when the nitrogen doses were increased.

When working with arugula, Affonso \& Cecílio (2009) observed a significant effect on the fresh mass of plants as a function of $\mathrm{N}$ doses, with highest fresh mass, $70.8 \mathrm{~g} \mathrm{plant}^{-1}$ obtained with $240 \mathrm{~kg} \mathrm{ha}^{-1}$ of $\mathrm{N}$, similar to the result found in this work.

According to the regression analysis performed for dry shoot mass, we could see that the data were described by a quadratic polynomial model, with $\mathrm{R}^{2}$ of $86 \%$, which indicates an excellent fit of the model to the data. By analyzing the estimated curve of dry mass accumulation, we noticed that the bell pepper plants were significantly influenced, with greater efficiency in the use of nitrogen for a maximum increase in dry mass at the optimal dose of $233.33 \mathrm{~kg} \mathrm{ha}^{-1}$. It corresponds to $85.54 \%$ of the dry mass production in comparison to its production at the zero 


\section{Macrothink

dose $(95.48 \mathrm{~g})$. Therefore, it is possible to not the importance of nitrogen in plant production and in the assimilation of carbon in the bell pepper crop (Aragão et al. 2011).

The effects of nitrogen on the plant phytomass reserve have also been observed by Vieira et al. (2016) and Medeiros et al. (2017), when studying other agricultural crops. Nitrogen promoted positive effects (growth and biomass accumulation) on plants due to its role in metabolism, as it participates in the molecule of chlorophyll, nucleic acids and proteins, besides being an activator of many enzymes (Malavolta, 2006).

Regarding the results of this work, we observed that nitrogen is required by bell peppers up to an optimal dose, since one of the strategies of the plant is to show its maximum production potential under the ideal dose of a nutrient. Thus, the nutritional supply may not be shown as a limiting factor to the yield of agricultural crops (Costa et al. 2015).

The result of this work may serve as a basis for the nitrogen management of bell pepper plants in the region, since to produce any vegetable with quality and in large quantities, it is necessary to provide the soil with all nutrients needed by the plant for its development, especially at the times of greatest nutritional demand (Morais et al., 2017). It is crucial to know the nutrient absorption curve and the accumulation of fresh and dry mass of the plant.

Since the optimal doses, 224.33, 256.09 and $233.33 \mathrm{~kg} \mathrm{ha}^{-1}$, found in this study for height of plants, fresh shoot mass and dry shoot mass, respectively, were much higher than those recommended by the fertilization bulletin of the Pará State, which proposes $150 \mathrm{~kg} \mathrm{ha}^{-1}$ via soil, for bell pepper cultivation.

The application of the ideal dose of a nutrient is one of the strategies that can be used for the plant to be able to express its maximum production potential. Thus, nutritional supply may not present itself as a limiting factor for the yield of agricultural crops.

Thus, considering the lack of information on the influence of $\mathrm{N}$ on fresh and dry mass of bell pepper, the results of this study demonstrate that, as it is an initial work in the northern region of Brazil, more experiments in this line of research are needed in order to obtain more consistent data for the crop in question.

The predawn water potential followed a quadratic curve $(P<0.05)$. The fitting equations $\left(\mathrm{R}^{2}>\right.$ 0.8 ) made it possible to estimate the tension of $39.83 \mathrm{kPa}$ and the nitrogen dose of $350 \mathrm{~kg} \mathrm{ha}^{-1}$ to obtain the maximum average water potential, -0.51 and $-0.39 \mathrm{MPa}$, respectively (Figure 6 and 7). 


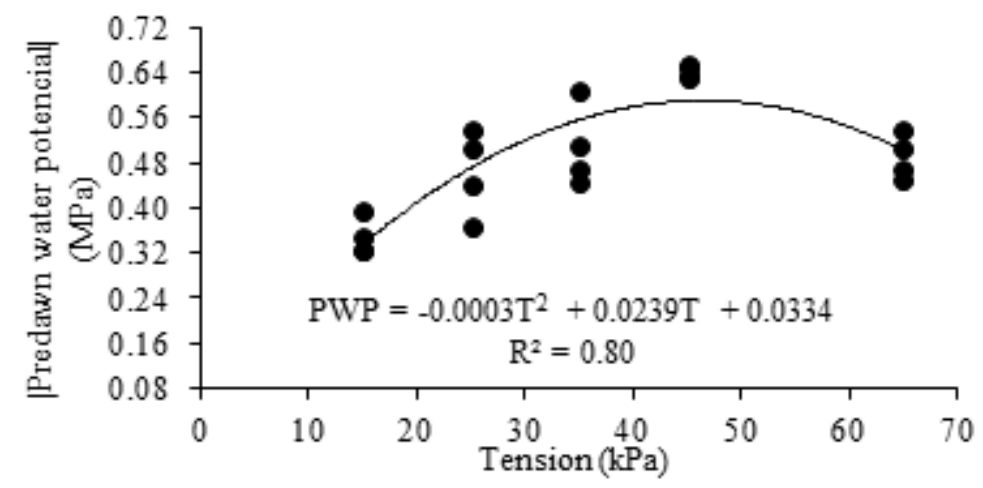

Figure 6. Effect of soil water tensions on the predawn water potential (PWP) in the bell pepper crop

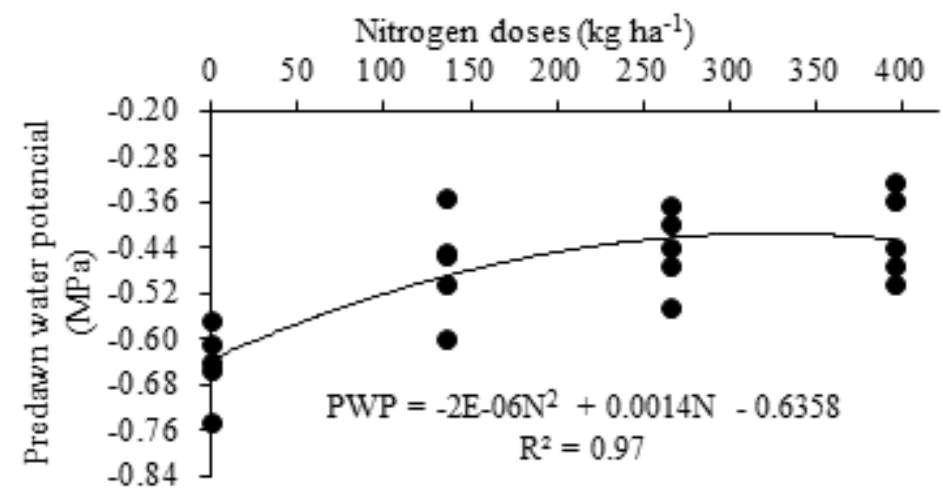

Figure 7. Effect of nitrogen doses on the predawn water potential (PWP) in the bell pepper crop For PWP, none of the treatments showed leaf water potential values greater than -1.00 MPa. This suggests that the plants at that time were not negatively affected by the applied tension. Marinho (2011), found lower values than those found in this work, $-0.76 \mathrm{MPa}$ at the vegetative phase and -0.77 MPa at the flowering phase of the cultivar Tabasco for the treatments that received $40 \%$ of the crop evapotranspiration. Possibly, the irrigation depth applied as a function of the increase in the nitrogen dose contributed to the maintenance of the plant turgor, by increasing its water potential.

It is well known that the leaf water potential is often reduced as water availability in the soil decreases. In the present study, there was no significant reduction in water potential in bell pepper plants during the stress period for each treatment, because as irrigation resumed, plants were able to recover from the water stress caused.

Despite the water recovery of the plants caused by water stress in the treatments with 45 and 65 $\mathrm{kPa}$ tensions, we could see a high fall of flowers and fruits. It directly affected the yield of these treatments, increasing the losses to approximately 49 and 53\% in the yield in the treatments, respectively. For Sezen et al. (2006), the high water content is related to the maintenance of tissue turgor, which is particularly important for photosynthesis, flowering, fruiting and product quality. 
During the nighttime, the plant has its maximum cellular turgor and, consequently, lowest intracellular solute concentration, when compared to the midday period. Therefore, healthy plants are expected to be able to hydrate to the maximum during the nighttime (Duarte, 2015). This could also be observed in this study, as the bell pepper plants, despite being subjected to stress, were able to hydrate in all treatments during the nighttime. However, it is necessary to conduct further research focused on this.

\section{Conclusion}

Given the conditions under which this work was performed and the results achieved for the cultivation of bell peppers in a greenhouse, it can be concluded that:

- The variables height of plants, fresh shoot mass and dry shoot mass obtained better results with nitrogen doses of 224.33, 256.09 and $233.33 \mathrm{~kg} \cdot \mathrm{ha}^{-1}$, reaching $77.65 \mathrm{~cm}, 1,151.49$ and $177.15 \mathrm{~g}$, respectively.

- The predawn water potential obtained the best results at the soil water tension of $39.83 \mathrm{kPa}$ and nitrogen dose of $350 \mathrm{~g} . \mathrm{kg}^{-1}$, being equal to $-0.51 \mathrm{MPa}$ and -0.3908 , respectively.

\section{Acknowledgements}

We thank CAPES - Coordination for the Improvement of Higher Education Personnel for granting the Master's Degree Scholarship and the Federal Rural University of Amazon for helping to publish this research.

\section{References}

Affonso, J. M. S., \& Cecílio Filho, A. B. (2009). Doses de nitrogênio na produtividade e qualidade de rúcula. Horticultura Brasileira, 2811-2818. CD ROM.

Aragão, V. F., Fernandes, P. D., Gomes Filho, R. R., Santos Neto, A. M., Carvalho, C. M., \& Feitosa, H. O. (2011). Efeito de diferentes lâminas de irrigação e níveis de nitrogênio na fase vegetativa do pimentão em ambiente protegido. Revista Brasileira de Agricultura Irrigada, 361-375. https://doi.org/10.7127/rbai.v5n400043

Araújo, J. S., Andrade, A. P., Ramalho, C. I., \& Azevedo, C. A. V. (2009). Cultivo do pimentão em condições protegidas sob diferentes doses de nitrogênio via fertirrigação. Revista Brasileira de Engenharia Agrícola e Ambiental, 152-157. https://doi.org/10.1590/S1415-43662009000500008

Aviz, W. L. C., Lima Junior, J. A., Silva, A. L. P., Gomes, R. F., Souza, R. O. R. M. E., Santos, H. C. A. \& Oliveira, P. D. (2019). Productivity of jambu (Acmella oleracea) using different soil water tensions and nitrogen rates under greenhouse condition. Australian Journal of Crop Science, 360-366. https://doi.org/10.21475/ajcs.19.13.03.p1178

Bilibio, C., Carvalho, J. A., Martins, M., Rezende, F. C., Freitas, E. A., \& Gomes, L. A. A. (2010). Desenvolvimento vegetativo e produtivo da berinjela submetida a diferentes tensões de água no solo. Revista Brasileira de Engenharia Agrícola e Ambiental, 730-735. https://doi.org/10.1590/S1415-43662010000700007 


\section{Ml Macrothink}

Journal of Agricultural Studies

ISSN 2166-0379

2020, Vol. 8, No. 2

Cabello, F. P. (1996). Riegos localizados de alta frecuencia (RLAF) goteo, microaspersión, exudasión. Madrid: Mundi-Prensa.

Campos, V. C., Oliveira, A. P., Cavalcante, L. F., \& Prazeres, S. da S. (2008). Rendimento do pimentão submetido ao nitrogênio aplicado via água de irrigação em ambiente protegido. Revista de Biologia e Ciências da terra. ISSN 1519-5228.

Carrijo, O. A., Souza, R. B., Marouelli, W. A., \& Andrade, R. J. (2004). Fertirrigação de hortaliças. Embrapa Hortaliças. Circular técnica, n. 32.

Carvalho, K. S., Koetz, M., Polizel, A. C., Cabral, C. E. A., \& Silva, C. R. M. (2013). Cultivo de pimentão vermelho submetido a tensões de água no solo. Enciclopédia Biosfera, 659-669.

Carvalho, P. G. (2005). Efeitos do nitrogênio no crescimento e no metabolismo de frutanos em Vernonia herbácea (VELL.) Rusby. (Dissertação de Mestrado). Escola Superior de Agricultura "Luiz de Queiroz", Piracicaba, São Paulo.

Costa, A. R., Rezende, R., Freitas, P. S. L., Gonçalves, A. C. A., \& Frizzone, J. A. (2015). A cultura da abobrinha italiana em ambiente protegido utilizando fertirrigação nitrogenada e potássica. Irriga. https://doi.org/10.15809/irriga.2015v20n1p105

Doorenbos, J., \& Kassam, A. H. (2000). Efeito da água no rendimento das culturas. Tradução Gheyi, H. R., Sousa, A. A., Damasceno, f. a. v., Medeiros, j. f. (2ªds.). Campina Grande: UFPB, 221p. (Estudos FAO: Irrigação e drenagem, 33).

Duarte, H. H. F. (2015). Status hídrico, fluorescência da clorofila e trocas gasosas em pimentão cultivado sob estresse salino. (Dissertação de Mestrado). Universidade Federal Rural de Pernambuco, Recife, Pernambuco.

Filgueira, F. A. R. (2008). Novo manual de olericultura: agrotecnologia moderna na produção e comercialização de hortaliças. Viçosa: UFV.

Flores, D. S. (2014). Manejo da irrigação sobre as características morfológicas e produtividade do pimentão em ambiente protegido. (Dissertação de Mestrado). Universidade do Estado da Bahia, Juazeiro, Bahia.

Loss, J. B. (2017). Desenvolvimento vegetativo e produtivo do pimentão submetido a tensões de água no solo. (Dissertação de Mestrado). Universidade Federal do Espirito Santo, Alegre, Espirito Santo.

Malavolta, E. (2006). Manual de nutrição mineral de plantas. Piracicaba: CERES.

Malavolta, E., Vitti, G. C., \& Oliveira, S. A. (1997). Avaliação do estado nutricional das plantas: princípios e aplicações. Piracicaba: POTAFOS.

Mantovani, E. C. (2001). AVALIA: Programa de Avaliação da Irrigação por Aspersão e Localizada. Viçosa: UFV.

Marinho, L. B. (2011). Irrigação plena e com déficit em pimenta cv. Tabasco em ambiente protegido. (Tese de Doutorado). Universidade de São Paulo Escola Superior de Agricultura 
“Luiz de Queiroz”, Piracicaba, São Paulo.

Marouelli, W. A. (2008). Tensiômetros para o controle de irrigação em hortaliças. Embrapa Hortaliças. Circular técnica, n. 57.

Marouelli, W. A., \& Silva, W. L. C. (2012). (1 ${ }^{\text {a }}$ Ed.). Irrigação na cultura do pimentão. Brasília, DF: Embrapa Circular Técnica.

Marouelli, W. A., \& Silva, W. L. C. (2014). Irrigação e fertirrigação na cultura do pimentão. In: Sousa, V. F., Marouelli, W. A., Coelho, E.F., Pinto, J. M., Coelho Filho, M. A. (2014) ( $2^{a}$ Eds.). Irrigação e fertirrigação em fruteiras e hortaliças. Brasília, DF: Embrapa Informação Tecnológica.

Medeiros, A. S., Nobre, R. G., Campos, A. C., Queiroz, M. M. F., Magalhães, I. D., \& Ferraz, R. L. S. (2017). Características biométricas e acúmulo de fitomassa da berinjeleira sob irrigação com água residuárias e doses de nitrogênio e fósforo. Revista Brasileira de Agricultura Irrigada, 1975-1985. https://doi.org/10.7127/rbai.v11n700665

Morais, E. G., Freire, M. M., Santos, A. Y. O., Silva Júnior, D. N., Costa, B. A. M., \& Silva, G. G. C. (2017). Acúmulo de matéria fresca e seca de plantas de rúcula. In: II Simpósio de Manejo de Solo e Água - SMSA, 2017, Mossoró. Anais... Mossoró: UFERSA.

Rincon, L., Saez, J., Balsalobre, E., \& Pellicer, C. (1995). Crecimiento y absorción de nutrientes del pimiento grueso bajo invernadero. Investigación Agraria, 47-59.

Santos, R. F., Klar, A. E., \& Frigo, E. P. (2003). Crescimento da cultura do pimentão cultivado na estufa plástica e no campo sob diferentes doses de nitrogênio e potássio. Irriga, 250-263. https://doi.org/10.15809/irriga.2003v8n3p250-263

Santos, R. F., Ricieri, R. P., Klar, A. E., \& Kruger, F. C. (1999). Compotamento de altura de planta de híbridos de pimentão cultivado na estufa e á campo. In: XI Congresso Brasileiro de Agrometeorologia - II Reunião Latino-Americana de Agrometeorologia, Flrorianópolis, 1999. CD-ROM.

Scholander, P. F., Hammel, H. T., Bradstreet E. D., \& Hemmingsen, E. A. (1965). Sap pressure in vascular plants. Science, 339-346. https://doi.org/10.1126/science.148.3668.339

Sezen, S. M., Yazar, A., \& Eker, S. (2006). Efeitos de regimes de irrigação no rendimento e qualidade em campo de pimenta. Agricultural Water Management, 115-131. https://doi.org/10.1016/j.agwat.2005.04.002

Silva, A. M., Lima, E. P., Coelho, M. R., \& Coelho, G. S. (2003). Produtividade, rendimento de grãos e comportamento hídrico foliar em função da época de irrigação do parcelamento e do método de adubação do cafeeiro catuaí. Engenharia Agrícola, 434-440.

Tobin, M. F., Lopez, O. R., \& Kursar, T. A. (1999). Responses of Tropical Understory Plants to a Severe Drought: Tolerance and Avoidance of Water Stress. Biotropica, 570-578. https://doi.org/10.1111/j.1744-7429.1999.tb00404.x

Van Genuchten, M. Th. (1980). A closed-form equation for predicting the hydraulic 


\section{Macrothink}

Journal of Agricultural Studies

ISSN 2166-0379 2020, Vol. 8, No. 2

conductivity of unsaturated soils. Soil Science Society of America Journal, 892-898. https://doi.org/10.2136/sssaj1980.03615995004400050002x

Vieira, I. G. S., Nobre, R. G., Dias, A. S., \& Pinheiro, F. W. A. (2016). Cultivation of cherry tomato under irrigation with saline water and nitrogen fertilization. Revista Brasileira de Engenharia Agrícola e Ambiental, 55-61. https://doi.org/10.1590/1807-1929/agriambi.v20n1p55-61

\section{Copyright Disclaimer}

Copyright for this article is retained by the author(s), with first publication rights granted to the journal.

This is an open-access article distributed under the terms and conditions of the Creative Commons Attribution license (http://creativecommons.org/licenses/by/4.0/). 